\title{
SISTEM MANAJEMEN PERSEDIAAN PADA BUNDA BAKERY DENGAN MENGIMPLEMENTASIKAN MATERIAL REQUIREMENT PLANNING (MRP)
}

\author{
Aisyah Fitri ${ }^{1}$, Istianah Muslim ${ }^{2}$ \\ ${ }^{12}$ Politeknik Caltex Riau \\ Jl. Umban sari, no.1, Riau \\ ${ }^{1}$ aisyahfitri@alumni.pcr.ac.id, ${ }^{2}$ istianah@pcr.ac.id
}

\begin{abstract}
Abstrak-Bunda Bakery merupakan bakery yang telah beroperasi sejak tahun 2017. Bunda Bakery memproduksi rotinya berdasarkan asumsi pemiliknya dan menyebabkan proses produksi yang tidak teratur. Sering terjadi overproduksi sehingga roti yang dihasilkan tidak layak untuk dijual. Hal ini juga mempengaruhi jumlah persediaan bahan baku yang tidak terkendali. Oleh karena itu diperlukan suatu sistem yang dapat membantu dalam pengendalian pasokan bahan baku dengan menggunakan teknik perhitungan Material Requirement Planning (MRP). Implementasi MRP juga didukung dengan menggunakan metode peramalan Single Exponential Smoothing dan metode Lot Sizing Fixed Order Quantity. Berdasarkan hasil pengujian yang dilakukan terhadap sistem informasi yang dibangun dengan menggunakan pengujian blackbox didapatkan bahwa $100 \%$ fungsionalitas sistem berjalan dengan baik. Pengujian penerimaan pengguna (UAT) yang dilakukan menunjukkan bahwa sistem yang dibangun dapat diterima oleh pengguna. Selanjutnya pengujian perbandingan akurasi metode menunjukkan bahwa hasil perhitungan yang ditampilkan pada sistem sudah akurat. Dan pengujian terakhir adalah uji usability, hasil pengujian menunjukkan rata-rata $89.95 \%$ pengguna sangat setuju dengan pembangunan sistem ini.
\end{abstract}

Kata Kunci- Material Requirement Planning; Single Exponential Smoothing; Lot Sizing Fixed Order Quantity; blackbox; user acceptance testing; usability test.

Abstract-Bunda Bakery is a bakery that has been operating since 2017. Bunda Bakery produces its bread based on the owner's assumption and causes an irregular production process. Overproduction often occurs so that the bread produced is not suitable for sale. This also affects the uncontrolled amount of raw material inventory. Therefore, we need a system that can assist in controlling the supply of raw materials by using the Material Requirement Planning (MRP) calculation technique. MRP implementation is also supported by using the Single Exponential Smoothing forecasting method and the Lot Sizing Fixed Order Quantity method. Based on the results of tests carried out on the information system built, using blackbox testing, it was found that $100 \%$ of the system's functionality was running well. User acceptance testing (UAT) testing that is carried out shows that the system being built can be accepted by the user. Furthermore, testing the comparison of method accuracy shows that the calculation results displayed on the system are accurate. And the last test is the usability test, the test results show an average of $\mathbf{8 9 . 9 5 \%}$ that users strongly agree with the construction of this system.

Keywords-Material Requirement Planning, Single Exponential Smoothing, Lot Sizing Fixed Order Quantity, blackbox, user acceptance testing, usability test.

\section{PENDAHULUAN}

\section{A. Latar belakang umum}

Bunda Bakery merupakan salah satu perusahaan manufaktur menghasilkan roti dengan berbagai jenis dan varian rasa. Pada setiap perusahaan manufaktur salah satu hal yang sangat perlu diperhatikan adalah manajemen persediaan. Manajemen persediaan adalah proses mengendalikan bahan keperluan produksi yang berguna dalam proses produksi bahan jadi untuk menunjang proses jual beli perusahaan. Perusahaan yang kurang mengontrol persediaan bahan baku akan mengalami pengeluaran biaya yang cukup besar dikarenakan bahan baku yang menumpuk atau bahan baku yang rusak karena terlalu lama disimpan di gudang.

Berdasarkan hasil wawancara yang dilakukan pada tanggal 18 dan 19 Mei 2019 dengan pemilik usaha Bunda Bakery, Ardi, diketahui bahwa produk yang paling laku dijual di Bunda Bakery adalah roti kk unyil dan dalam proses produksinya, usaha ini belum dapat mengontrol proses pengadaan bahan baku, sehingga pemilik usaha tidak mengetahui kapan waktu yang tepat untuk melakukan pengadaan bahan baku. Hal ini menyebabkan produksi roti yang dilakukan menyesuaikan dengan ketersediaan bahan baku yang ada pada saat proses produksi dilaksanakan bukan berdasarkan data kebutuhan penjualan. Proses produksi 
yang tidak sesuai dengan kebutuhan ini mengakibatkan terjadinya kelebihan stok roti di toko sehingga roti tersebut berjamur dan tidak layak dijual.

Mengenai hal tersebut, perlu adanya sebuat teknik pengendalian persediaan bahan baku pada usaha Bunda Bakery. Salah satu teknik yang bisa digunakan adalah penggunaan teknik Material Requirement Planning (MRP). Teknik MRP ini dapat diimplementasikan kedalam sebuah sistem informasi. Yang mana dengan menggunakan sebuah sistem informasi dapat mengelola data lebih cepat, efisien, dan efektif bagi usaha Bunda Bakery. Dengan sistem ini proses pencatatan penjualan dan pengadaan bahan baku akan lebih tertata rapi dan jelas.

Dalam melakukan perhitungan MRP dibutuhkan perhitungan peramalan produksi dan lot sizing. Berdasarkan hasil wawancara lanjutan dengan pemilik usaha pada tanggal 8 Juni 2019, produksi pada Bunda Bakery dilakukan sekitar dua sampai tiga kali dalam seminggu. Sehingga dalam proses perhitungan peramalan produksi menggunakan data historis penjualan setiap minggunya dari bulan oktober 2018 sampai juni 2019.

Proses perhitungan peramalan produksi ini menggunakan data historis penjualan, sehingga termasuk kedalam kategori peramalan kuantitatif, sehingga metode peramalan yang digunakan yaitu single exponential smoothing. Setelah dapat menentukan perencanaan produksi maka diperlukannya proses pengadaan barang baku dengan metode lot sizing fixed order quantity. Sedangkan untuk mengontrol persediaan, perhitungan ROP digunakan agar perusahaan dapat mengetahui kapan waktunya melakukan pemesanan dan bagaimana jumlah persediaan saat itu.

Berdasarkan hal tersebut, maka dalam penelitian ini dilakukan perancangan sistem manajemen persediaan pada Bunda Bakery sehingga dengan adanya sistem ini perusahaan dapat diperoleh informasi penjadwalan proses pengadaan bahan baku dan dapat mengontrol persediaan bahan baku.

\section{B. Kajian literatur terdahulu}

Penelitian pertama yaitu penelitian yang dilakukan oleh (Ade \& Syaichu, 2016). Adapun penelitian ini mengambil studi kasus pada PT. Semen Indonesia pabrik Tuban [1]. Penelitian ini menggunakan metode Dynamix Lot Sizing dalam pengendalian biaya persediaannya. Dari hasil perhitungan dengan menggunakan model Dynamic Lot Sizing, diperoleh bahan baku gypsum sebesar Rp 2.441.767.132,- tanah liat sebesar $\mathrm{Rp}$ 4.391.873.999,- pasir besi sebesar $\mathrm{Rp}$ 942628181 perusahaan dapat menghasilkan total biaya sebesar Rp 7.776.440.327,- dan menghasilkan efisiensi penghematan sebesar 10,25\% dibandingkan dengan total biaya sebelumnya yaitu sebesar Rp 8.664.631.430,
Penelitian kedua yaitu penelitian yang dilakukan oleh (Wibisono, Rahayuningsih, \& Santoso, 2017). Setelah menganalisis beberapa metode peramalan maka metode peramalan yang tepat digunakan pada PT. Latif di Kediri ini adalah metode Moving Average dan untuk metode pada pengendalian bahan baku yang sesuai adalah metode Lot Sizing Lot for Lot [2]. Dari hasil penghitungan kedua lot sizing dapat diambil kesimpulan bahwa penerapan metode Lot Sizing Lot for Lot untuk setiap bahan baku SH-15 pada PT. Latif dapat meminimalkan biaya total persediaan sebesar Rp 60.000,- apabila dibandingkan dengan metode Lot Sizing Part Period Balancing.

Penelitian ketiga yaitu penelitian yang dilakukan oleh (Kusumawati \& Setiawan, 2017). Pada penelitian ini juga dilakukan perbandingan dari beberapa metode untuk peramalan produksi dan metode untuk pengendalian persediaan bahan baku [3]. Dari hasil perbandingan, metode yang sesuai pada studi kasus ini adalah metode Single Moving Average (SMA) untuk peramalan dan metode Lot Sizing Period Order Quantity (POQ) untuk pengendalian persediaan bahan baku. Dengan menggunakan metode Single Moving Average (5 bulan) dengan nilai standart error yang terkecil dengan nilai $\mathrm{MAPE}=6, \quad \mathrm{MAD}=1731$, $\mathrm{MSD}=3499000$. Penggunaan Lot Sizing POQ memiliki total biaya persediaan paling kecil sebesar Rp. 85.281,dibandingkan dengan perhitungan LFL dan EOQ yang mampu meminimalisasikan biaya persediaan sebesar $41 \%$.

Penelitian selanjutnya yaitu penelitian yang dilakukan oleh (Maharani, 2018). Penelitian ini berbeda dari penelitian yang telah dijabarkan sebelumnya, karena pada penelitian ini tidak membandingkan beberapa metode [4]. Pada penelitian ini menggunakan metode permalan single exponential smoothing dan metode pengendalian persediaan bahan baku dengan menggunakan metode fixed order quantity (FOQ). Adapun hasil dari sistem yang dibangun adalah untuk membantu pengguna mendapatkan informasi pemesanan dan pendistribusian bahan baku apabila ada bahan baku yang kurang ataupun habis pada tiap-tiap toko.

Penelitian terakhir yaitu penelitian yang dilakukan oleh (Solahuddin \& Andari, 2018). Perhitungan yang direkomendasikan akan dianalisis dengan analisis sensitivitas untuk mengetahui hasil terhadap inflasi Bank Indonesia [5]. Hasil penelitian merekomendasikan bahwa MRP LFL memberikan solusi optimal dan paling hemat biaya dibandingkan dengan perhitungan perusahaan dan MRP teknik (EOQ), dan hasil analisis sensitivitas menghasilkan metode tersebut tidak berpengaruh terhadap inflasi.

\section{Tujuan penelitian}

Adapun tujuan dari penelitian ini ialah menentukan jadwal pemesanan bahan baku, mengontrol keluar dan masuknya bahan baku, dan merencanakan produksi roti pada Bunda Bakery. 


\section{METODE PENELITIAN}

Page | 116 adalah:

Metode penelitian yang digunakan dalam penelitian ini

1) Wawancara : Tujuan dari metode ini adalah untuk mengumpulkan informasi yang diperlukan dalam penelitian ini.

2) Studi Literatur : Pada studi literatur, dilakukan kegiatan mengumpulkan serta mempelajari referensi mengenai sistem informasi persediaan, material requirement planning, single exponential smoothing, fixed order quantity.

3) Pengambilan Data : Pada kegiatan ini, dilakukan pengambilan data berupa data penjualan roti dari Bunda Bakery.

4) Perancangan : Melakukan perancangan dengan merancang block diagram, arsitektur sistem, hingga prototype dari sistem. Perancangan didasarkan dari tujuan dan manfaat dari pembuatan sistem dimana terdapat metode perhitungan Single Exponential Smoothing, Fixed Order Quantity (FOQ), serta terdapat pemrograman berorientasi objek didalamnya.

5) Pengujian : Melakukan pengujian terhadap keberhasilan sistem terhadap metode perhitungan Single Exponential Smoothing, Fixed Order Quantity (FOQ), Material Requirement Planning $(M R P)$.

6) Analisis dan Evaluasi : Pada kegiatan ini, dilakukan analisis terhadap sistem dalam menentukan jumlah pembelian bahan baku berdasarkan perhitungan Material Requirement Planning (MRP).

\section{HASIL DAN ANALISIS}

\section{A. Desain software}

Dalam membangun sebuah sistem informasi diperlukan pembuatan desain database, desain sistem dan desain antarmuka.

1) Desain database

Seluruh data pada sistem disimpan didalam database. Desain database digambarkan dengan Entity Relationship Diagram (ERD). Perancangan ERD dapat dilihat pada gbr 1.

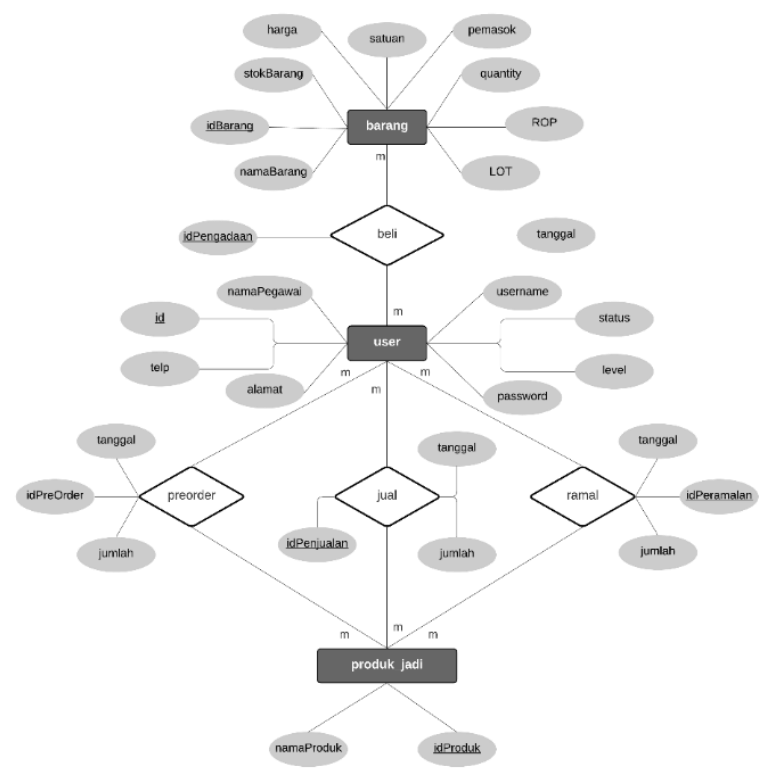

Gbr. 1 Perancangan ERD

2) Desain sistem

Desain pada sistem merupakan perancangan dalam membangun fitur-fitur yang diperlukan. Desain sistem dapat dibuat dengan menggunakan use case diagram. Perancangan usa case diagram dapat dilihat pada gbr 2 .

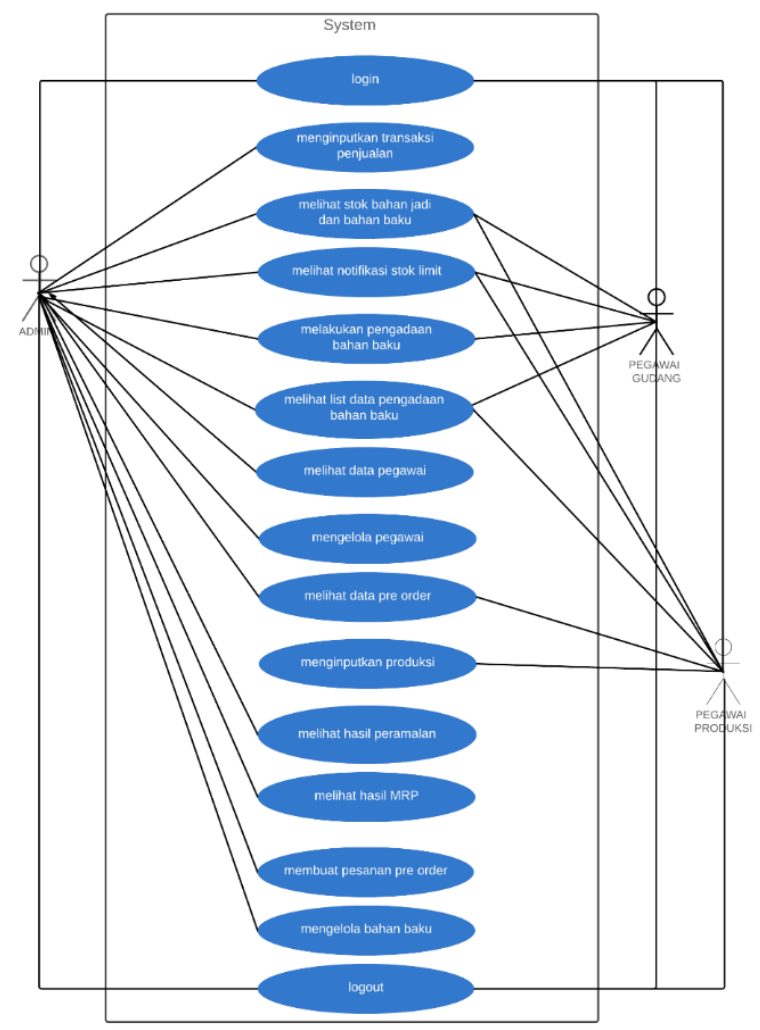

Gbr. 2 Use case diagram.

Use case diagram dapat menjelaskan hak akses dari setiap actor pada sistem. Pada gbr 2 dapat dilihat bahwa pada sistem ini memiliki tiga actor yang dapat 
mengakses sistem dengan masing-masing fitur yang dapat diaksesnya.

3) Desain antarmuka

a. Halaman login

Page | 117 Sistem ini dapat diakses oleh 3 aktor yaitu admin (pemilik usaha), pegawai produksi, dan pegawai gudang. Setiap aktor memiliki hak akses masingmasing dalam menggunakan sistem ini. Untuk dapat menggunakan sistem, setiap aktor diharuskan untuk melakukan login dengan menginputkan username dan password pada form login yang disediakan. Halaman login dapat dilihat pada gbr 3 .

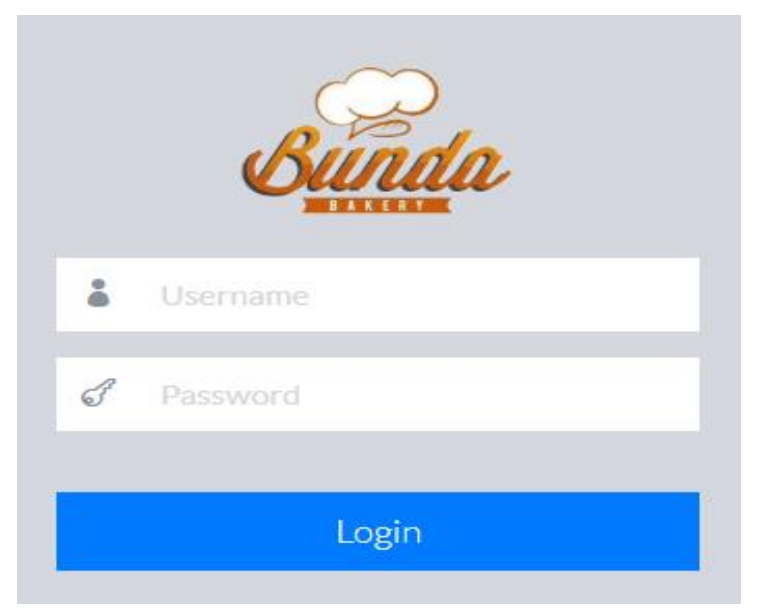

Gbr. 3 Halaman login

b. Halaman Dashboard

Jika username dan password yang diinputkan benar, maka aktor akan diarahkan ke halaman home masingmasing. Tetapi jika inputan yang dimasukkan salah atau tidak terisi maka akan muncul pesan gagal dan pengguna harus menginputkan username dan password kembali. Halaman dashboard pengguna dapat dilihat pada gbr 4.

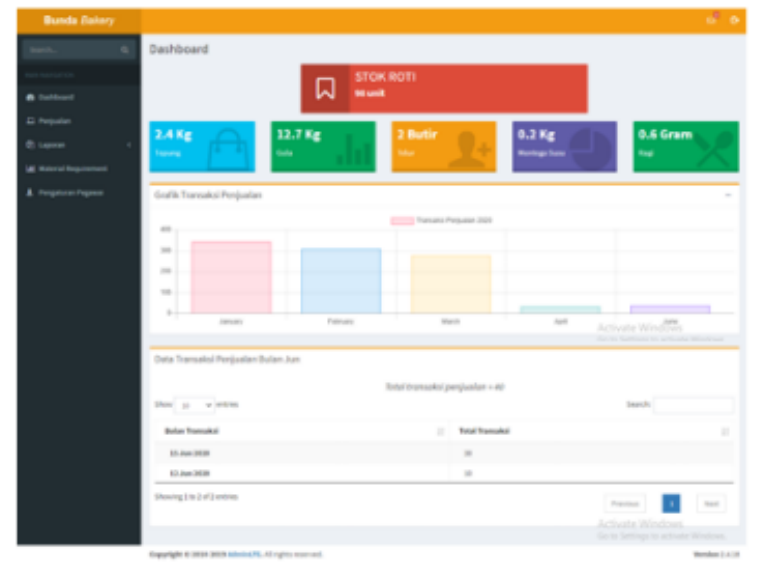

Gbr. 4 Halaman Dashboard

c. Halaman penjualan

Selanjutnya terdapat menu penjualan yang hanya dapat diakses oleh admin. Halaman penjualan ini akan menampilkan data penjualan yang direkap per bulannya. Halaman penjualan tersebut dapat dilihat pada gbr 5 dan detail data penjualan pada gbr 6 .

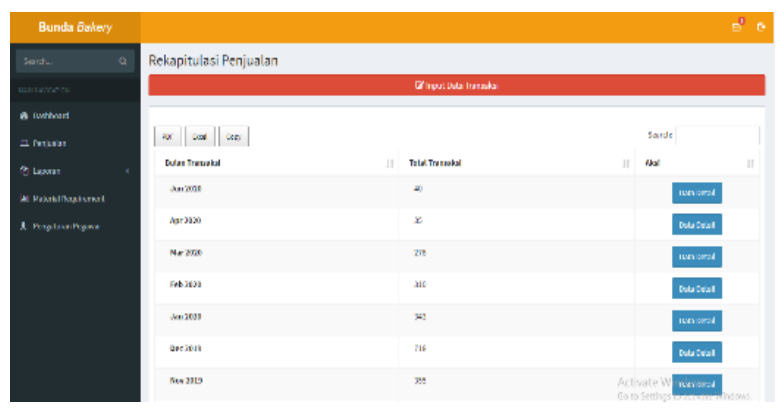

Gbr. 5 Halaman Penjualan

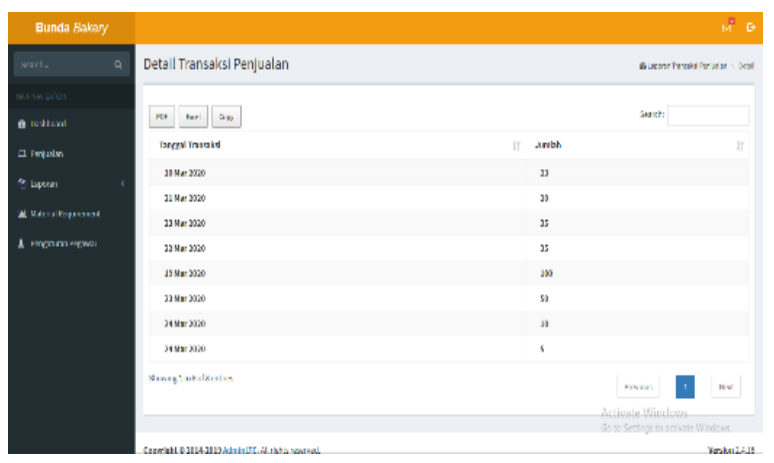

Gbr. 6 Halaman Detail Data Penjualan

\section{d. Halaman laporan}

Selanjutnya pada menu laporan terdapat tiga pilihan submenu yaitu persediaan bahan baku, data barang masuk, dan data pre order. Tampilan laporan persediaan bahan baku dapat dilihat pada gbr 7 .

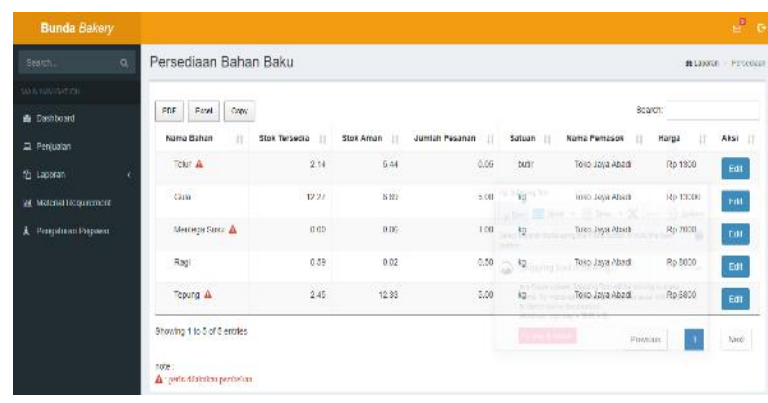

Gbr. 7 Halaman Laporan Persediaan Bahan Baku

Gbr 8 merupakan tampilan laporan data barang masuk atau data pengadaan bahan baku.

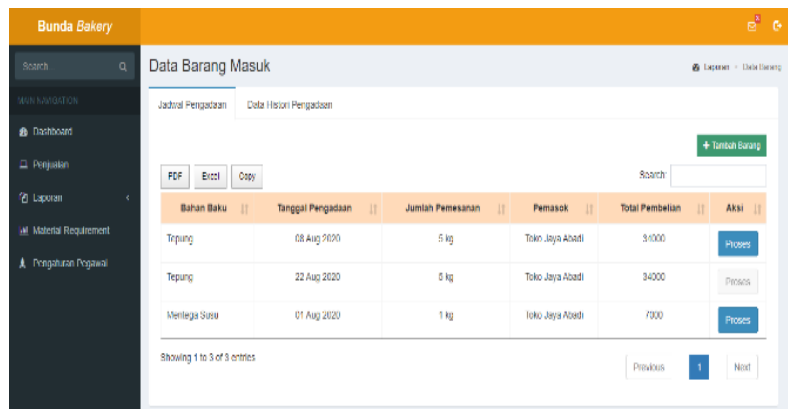

Gbr. 8 Halaman Laporan Data Barang Masuk 

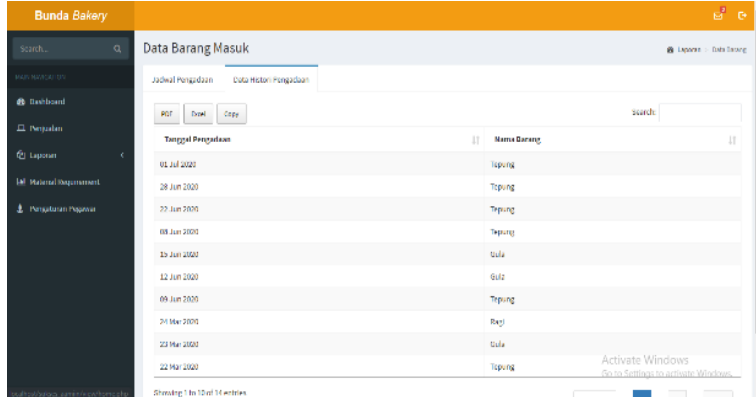

Gbr. 9 Halaman List Data Pengadaan

Gbr 10 menampilkan histori data pengadaan yang pernah dilakukan. Submenu yang terakhir pada menu laporan adalah data pre order yang ditampilkan pada gbr 10.

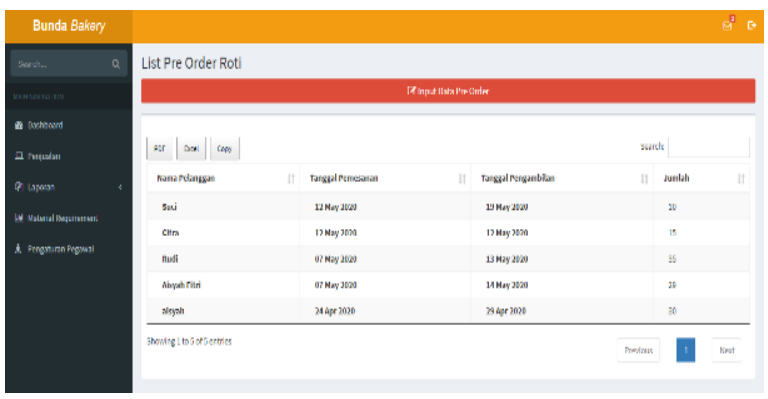

Gbr. 10 Halaman Laporan Data Pre Order

e. Halaman material requirement

Selanjutnya pada menu material requirement terdapat hasil peramalan, persediaan bahan baku, data kebutuhan produksi, dan jadwal pengadaan bahan baku. Data tersebut ditampilkan pada gbr 11 s.d gbr 14 .

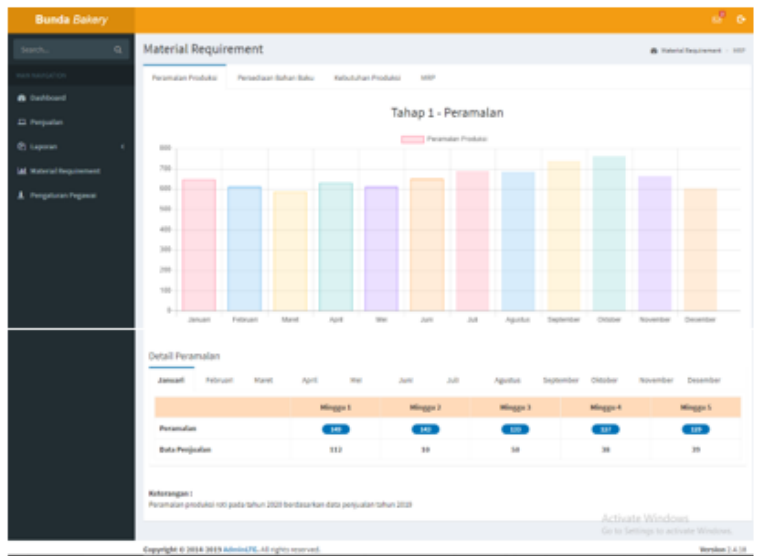

Gbr. 11 Halaman Hasil Peramalan Produksi

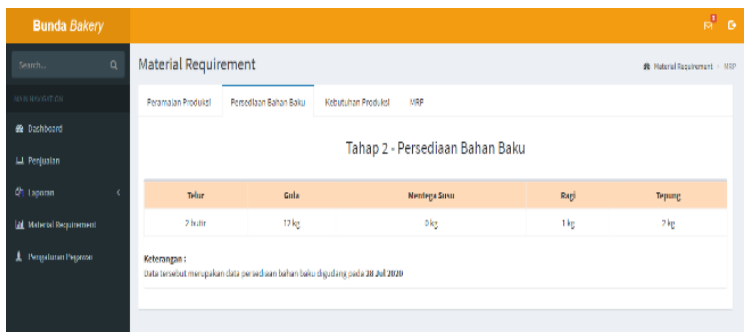

gbr 12 Halaman Data Persediaan Bahan Baku

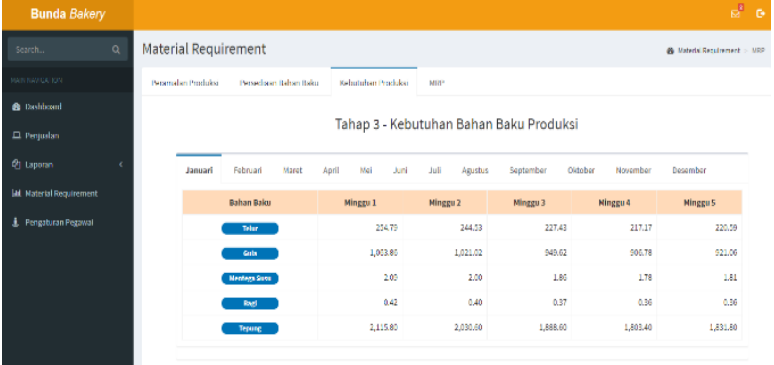

Gbr. 13 Halaman Data Kebutuhan Produksi

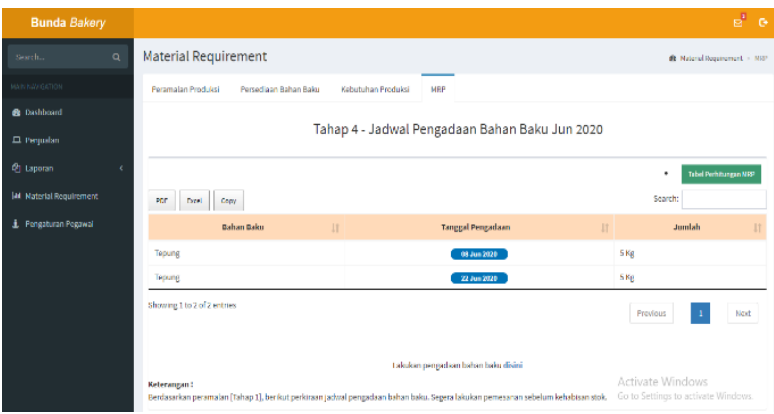

Gbr. 14 Halaman Jadwal Pengadaan Bahan Baku

f. Halaman pengaturan pegawai

Menu terakhir yang ada pada sistem ini adalah menu pengaturan pegawai. Pada menu ini akan ditampilkan data pegawai seperti pada gbr 15 .

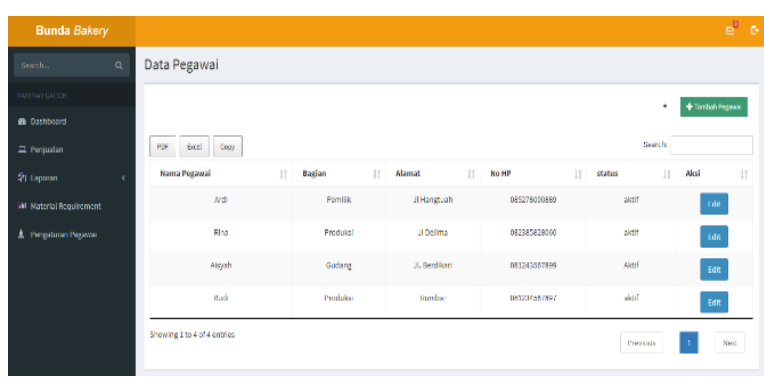

Gbr. 15 Halaman Pengaturan Pegawai

\section{B. Pengujian}

Salah satu pengujian yang dilakukan adalah Black Box Testing. Pengujian ini dilakukan untuk mengetahui apakah semua fitur pada sistem berfungsi dengan benar. Berdasarkan pengujian yang telah dilakukan kepada tiga responden, seluruh butir uji menunjukkan keterangan berhasil yang menandakan bahwa seluruh fungsi pada sistem berfungsi dengan baik. Hasil pengujian black box dapat dilihat pada tabel 1 .

TABEL I

HASIL PENGUJIAN BLACKBOX

\begin{tabular}{|c|l|l|c|}
\hline $\begin{array}{c}\mathbf{N} \\
\mathbf{0}\end{array}$ & Kelas Uji & \multicolumn{1}{|c|}{ Hasil } & Ket. \\
\hline 1. & $\begin{array}{l}\text { Halaman } \\
\text { Login }\end{array}$ & $\begin{array}{l}\text { Menampilkan pesan } \\
\text { gagal jika username } \\
\text { tidak diisi }\end{array}$ & Berhasil \\
\hline 2. & $\begin{array}{l}\text { Halaman } \\
\text { Dashboard }\end{array}$ & $\begin{array}{l}\text { Menampilkan } \\
\text { informasi stok }\end{array}$ & Berhasil \\
\hline
\end{tabular}




\begin{tabular}{|c|c|c|c|}
\hline $\mathbf{N}$ & Kelas Uji & Hasil & Ket. \\
\hline & & $\begin{array}{l}\text { produk jadi, stok } \\
\text { bahan baku, grafik } \\
\text { transaksi penjualan, } \\
\text { detail data } \\
\text { penjualan per } \\
\text { bulan, dan data } \\
\text { peramalan. }\end{array}$ & \\
\hline 3. & $\begin{array}{l}\text { Halaman } \\
\text { Penjualan }\end{array}$ & $\begin{array}{l}\text { Menampilkan } \\
\text { informasi transaksi } \\
\text { penjualan per } \\
\text { bulan. }\end{array}$ & Berhasil \\
\hline 4. & $\begin{array}{l}\text { Halaman } \\
\text { Laporan }\end{array}$ & $\begin{array}{l}\text { Menampilkan list } \\
\text { data persediaan } \\
\text { bahan baku }\end{array}$ & Berhasil \\
\hline 5. & $\begin{array}{l}\text { Halaman } \\
\text { Material } \\
\text { Requireme } \\
\text { nt }\end{array}$ & $\begin{array}{l}\text { Menampilkan hasil } \\
\text { peramalan produksi } \\
\text { berupa grafik dan } \\
\text { detail data perbulan }\end{array}$ & Berhasil \\
\hline 6. & $\begin{array}{l}\text { Halaman } \\
\text { Pengaturan } \\
\text { Pegawai }\end{array}$ & $\begin{array}{l}\text { Menampilkan list } \\
\text { data pegawai }\end{array}$ & Berhasil \\
\hline
\end{tabular}

Pengujian UAT ini dilakukan langsung kepada pengguna sistem yaitu pemilik usaha (admin), pegawai produksi, dan pegawai gudang. Hasil pengujian menunjukkan bahwa sistem yang dibangun beserta fitur yang terdapat didalamnya sesuai dengan kebutuhan usaha. Berikut salah satu dokumentasi hasil pengujian UAT yang telah dilakukan dapat dilihat pada gbr 16 .
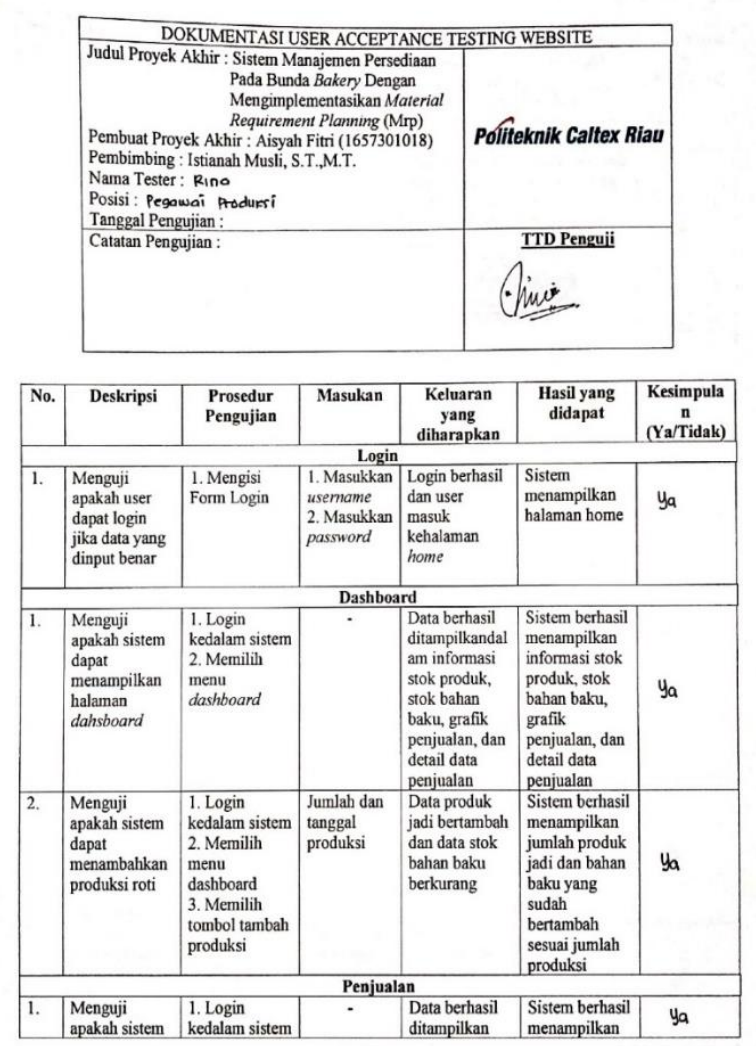

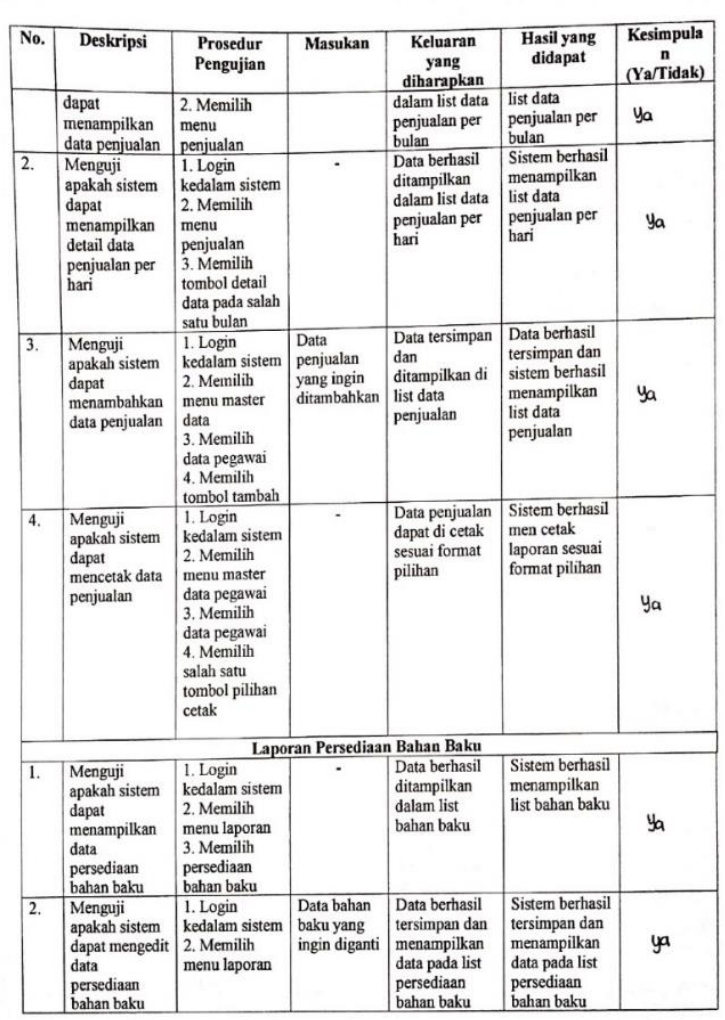

Gbr. 16 Dokumentasi pengujian UAT

Pengujian perbandingan akurasi metode ini dilakukan untuk mengetahui bahwa hasil perhitungan yang ditampilkan oleh sistem telah akurat dan sesuai dengan perhitungan manual yang dilakukan di Microsoft Excel. Pada gbr 17 dapat dilihat bahwa hasil perhitungan manual dan sistem sesuai.

\begin{tabular}{|r|c|c|c|}
\hline \multicolumn{4}{|c|}{ JANUARI } \\
\hline Period & Demand & Level & Forcast \\
\hline $\boldsymbol{t}$ & \multicolumn{1}{|c|}{$\boldsymbol{t}$} & $\boldsymbol{L} \boldsymbol{t}$ & $\boldsymbol{F t}$ \\
\hline 1 & 94 & 136 & 147 \\
\hline 2 & 131 & 135 & 136 \\
\hline 3 & 116 & 131 & 135 \\
\hline 4 & 66 & 118 & 131 \\
\hline 5 & 89 & 112 & 118 \\
\hline
\end{tabular}

Gbr. 17 Hasil peramalan produksi pada bulan januari dengan perhitungan manual

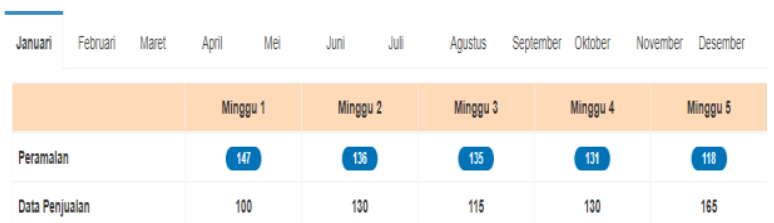

Gbr. 18 Hasil peramalan produksi pada bulan januari berdasarkan perhitungan sistem

Pengujian usability test ini dilakukan kepada 3 responden yang masing-masing responden mewakili setiap aktor yang menggunakan sistem ini. Dimana responden tersebut telah menggunakan sistem sebelum mengisi kuesioner yang disediakan. Hasil pengujian dilihat pada tabel 2 . 
TABEL II

HASIL PENGUJIAN USABILITY

\begin{tabular}{|c|c|c|c|}
\hline No & Butir Kriteria & $\begin{array}{c}\text { Persen } \\
\text { tase }\end{array}$ & Ket. \\
\hline \multicolumn{4}{|c|}{ USEFULNESS } \\
\hline 1 & $\begin{array}{l}\text { Sistem manajemen } \\
\text { persediaan bahan baku } \\
\text { ini membantu saya lebih } \\
\text { efektif }\end{array}$ & $93 \%$ & $\begin{array}{c}\text { Sangat } \\
\text { Baik }\end{array}$ \\
\hline 2 & $\begin{array}{l}\text { Sistem manajemen } \\
\text { persediaan bahan baku } \\
\text { ini sangat bermanfaat }\end{array}$ & $87 \%$ & $\begin{array}{c}\text { Sangat } \\
\text { Baik }\end{array}$ \\
\hline 3 & $\begin{array}{l}\text { Informasi yang } \\
\text { disediakan pada sistem } \\
\text { manajemen persediaan } \\
\text { bahan baku ini sudah } \\
\text { sesuai dengan kebutuhan }\end{array}$ & $80 \%$ & $\begin{array}{c}\text { Sangat } \\
\text { Baik }\end{array}$ \\
\hline 4 & $\begin{array}{l}\text { Sistem manajemen } \\
\text { persediaan bahan baku } \\
\text { sesuai dengan yang saya } \\
\text { harapkan }\end{array}$ & $80 \%$ & $\begin{array}{c}\text { Sangat } \\
\text { Baik }\end{array}$ \\
\hline \multicolumn{4}{|c|}{ EASE OF USE } \\
\hline 5 & $\begin{array}{l}\text { Sistem manajemen } \\
\text { persediaan bahan baku } \\
\text { ini mudah untuk } \\
\text { digunakan }\end{array}$ & $93 \%$ & $\begin{array}{c}\text { Sangat } \\
\text { Baik }\end{array}$ \\
\hline 6 & $\begin{array}{l}\text { Sistem manajemen } \\
\text { persediaan bahan baku } \\
\text { ini mudah untuk } \\
\text { digunakan }\end{array}$ & $93 \%$ & $\begin{array}{c}\text { Sangat } \\
\text { Baik }\end{array}$ \\
\hline 7 & $\begin{array}{l}\text { Sistem manajemen } \\
\text { persediaan bahan baku } \\
\text { ini dapat disesuaikan } \\
\text { dengan kebutuhan }\end{array}$ & $100 \%$ & $\begin{array}{c}\text { Sangat } \\
\text { Baik }\end{array}$ \\
\hline 8 & $\begin{array}{l}\text { Saya tidak kesulitan } \\
\text { menggunakan sistem } \\
\text { manajemen persediaan } \\
\text { bahan baku ini }\end{array}$ & $93 \%$ & $\begin{array}{c}\text { Sangat } \\
\text { Baik }\end{array}$ \\
\hline 9 & $\begin{array}{l}\text { Saya dapat } \\
\text { menggunakan sistem } \\
\text { manajemen persediaan } \\
\text { bahan baku ini tanpa } \\
\text { instruksi tertulis }\end{array}$ & $93 \%$ & $\begin{array}{c}\text { Sangat } \\
\text { Baik }\end{array}$ \\
\hline 10 & $\begin{array}{l}\text { Saya tidak melihat } \\
\text { adanya ketidak } \\
\text { konsistenan selama saya } \\
\text { menggunakannya }\end{array}$ & $80 \%$ & $\begin{array}{c}\text { Sangat } \\
\text { Baik }\end{array}$ \\
\hline \multicolumn{4}{|c|}{ EASE OF LEARNING } \\
\hline 11 & $\begin{array}{l}\text { Sistem manajemen } \\
\text { persediaan bahan baku } \\
\text { ini mudah saya pahami }\end{array}$ & $100 \%$ & $\begin{array}{c}\text { Sangat } \\
\text { Baik }\end{array}$ \\
\hline 12 & $\begin{array}{l}\text { Saya belajar } \\
\text { menggunakan sistem } \\
\text { manajemen persediaan } \\
\text { bahan baku ini dengan } \\
\text { cepat }\end{array}$ & $100 \%$ & $\begin{array}{c}\text { Sangat } \\
\text { Baik }\end{array}$ \\
\hline 13 & $\begin{array}{l}\text { Saya mudah mengingat } \\
\text { bagaimana cara } \\
\text { menggunakan sistem }\end{array}$ & $87 \%$ & $\begin{array}{c}\text { Sangat } \\
\text { Baik }\end{array}$ \\
\hline
\end{tabular}

\begin{tabular}{|c|c|c|c|}
\hline No & Butir Kriteria & $\begin{array}{c}\text { Persen } \\
\text { tase }\end{array}$ & Ket. \\
\hline & $\begin{array}{l}\text { manajemen persediaan } \\
\text { bahan baku ini }\end{array}$ & & \\
\hline 14 & $\begin{array}{l}\text { Sistem manajemen } \\
\text { persediaan bahan baku } \\
\text { ini mudah untuk } \\
\text { dipelajari cara } \\
\text { penggunaannya }\end{array}$ & $80 \%$ & $\begin{array}{c}\text { Sangat } \\
\text { Baik }\end{array}$ \\
\hline 15 & $\begin{array}{l}\text { Saya bisa menggunakan } \\
\text { Sistem manajemen } \\
\text { persediaan bahan baku } \\
\text { ini dalam waktu yang } \\
\text { singkat }\end{array}$ & $80 \%$ & $\begin{array}{c}\text { Sangat } \\
\text { Baik }\end{array}$ \\
\hline \multicolumn{4}{|c|}{ STATISFACTION } \\
\hline 16 & $\begin{array}{l}\text { Saya puas dengan sistem } \\
\text { manajemen persediaan } \\
\text { bahan baku ini }\end{array}$ & $87 \%$ & $\begin{array}{c}\text { Sangat } \\
\text { Baik }\end{array}$ \\
\hline 17 & $\begin{array}{l}\text { Sistem manajemen } \\
\text { persediaan bahan baku } \\
\text { ini menyenangkan untuk } \\
\text { digunakan }\end{array}$ & $93 \%$ & $\begin{array}{c}\text { Sangat } \\
\text { Baik }\end{array}$ \\
\hline 18 & Sistem ini sangat bagus & $87 \%$ & $\begin{array}{c}\text { Sangat } \\
\text { Baik }\end{array}$ \\
\hline 19 & $\begin{array}{l}\text { Sistem ini nyaman ketika } \\
\text { digunakan }\end{array}$ & $100 \%$ & $\begin{array}{c}\text { Sangat } \\
\text { Baik }\end{array}$ \\
\hline 20 & $\begin{array}{l}\text { Sistem ini bekerja seperti } \\
\text { yang saya inginkan }\end{array}$ & $100 \%$ & $\begin{array}{c}\text { Sangat } \\
\text { Baik }\end{array}$ \\
\hline
\end{tabular}

\section{UCAPAN TERIMA KASIH}

Terima kasih kepada Politeknik Caltex Riau telah memberikan kesempatan kepada peneliti untuk melakukan penelitian ini. Dan terima kasih juga kepada pemilik Bunda Bakery yang telah mengizinkan peneliti menjadikan usahanya sebagai tempat untuk melakukan penelitian ini.

\section{REFERENSI}

[1] Ade, P. I., \& Syaichu, A. (2016). Pengendalian Persediaan Bahan Baku Dengan Metode Material Requirement Planning (MRP) Pada PT. Semen Indonesia (PERSERO), Tbk. 22.

[2] Anhar. (2010). Panduan Menguasai PHP \& MySQL secara Otodidak. Jakarta: MediaKita.

[3] Binarso, Y. A. (2012). Pembangunan Sistem Informasi Alumni Berbasis Web pada Program Studi Teknik Informatika Universitas Diponerogo. Journal of Informatics and Technology, 73-74.

[4] Chopra, S., \& Meindl, P. (2007). Supply Chain Management: Strategy, Planning, and Operation. Upper Saddle River: Pearson Education, Inc.

[5] Gaspersz, V. (2002). Production Planing and Inventory Control. Jakarta: PT. Gramedia Pustaka Utama.

[6] Ishak. (2010). Manajemen Operasi. Yogyakarta: Graha Ilmu.

[7] Kusumawati, A., \& Setiawan, A. D. (2017). Analisis Pengendalian Persediaan Bahan Baku Tempe Menggunakan Material Requirement Planning. 168-173.

[8] Laudon, K. C., \& Laudon, J. P. (2005). Sistem Informasi Manajemen Mengelola Perusahaan Digital, Edisi 8. Yogyakarta: CV Andi Offset.

[9] Maharani, S. N. (2018). Implementasi MRP Untuk Pengendalian Persediaan Bahan Baku dan Meminimalkan Biaya Persediaan (Studi Kasus: Martabak Djoeragan). 
[10] Pakaja, F., Naba, A., \& Purwanto. (2012). Permalan penjualan Mobil Menggunakan Jaringan Syaraf Tiruan dan Certainly Factor. Jurnal EECCIS, Vol.6, No.1.

[11] Pratama, I. A. (2014). Sistem Informasi dan Implementasinya. Bandung: Informatika Bandung.

[12] Prayama, D. (2015). Sistem Monitoring Ruangan berbasis Raspberry Pi dan Motion. 30.

Page | 121 [13] Render, B., M. Stair, J. R., \& Hanna, M. E. (2012). Quantitative Analysis for Management (11th Edition). New Jersey: Pearson Prentice Hall.

[14] Solahuddin, A., \& Andari, T. T. (2018). Analisis Pengendalian Persediaan Untuk Meminimalkan Biaya Pada Bahan Kemasan Botol 70 ML 8 Gram DI PT. Milko Beverage Industry Bogor.

[15] Wibisono, G., Rahayuningsih, S., \& Santoso, H. B. (2017). Analisis Penerapan MRP Terhadap Perencanaan Dan Pengendalian Persediaan Bahan Baku Pada PT. Latif Di Kediri. 46. 